\section{Virological Results}

Altogether, eight infants were infected with R.S. virus, the virus being identified in all cases by direct examination of cells in aspirated material by the fluorescent antibody technique. In six of these patients the virus was subsequently isolated on tissue culture. The two in whom virus was not cultured were babies who had been ill for 5 and 14 days, respectively, before isolation attempts were made. The failure to culture virus in these two infants is not surprising, considering the long interval between the onset of illness and their examination for the presence of virus agents. In 17 older children investigated in this laboratory the presence of R.S. virus was found by direct examination of secretion collected on the day of admission and again seven days later, but culture of virus was achieved from the first specimen only. It appears that virus antigen can still be detected by immunofluorescence even after infectivity has been lost (Gardner and McQuillin, 1970). In one case virus antigen could still be detected in cells of the nasopharynx by the fluorescent antibody technique as long as 18 days after the onset of symptoms.

\section{COMMENT}

This report of an outbreak of an R.S. virus infection in a maternity hospital illustrates that mild respiratory illness caused by R.S. virus may occur at a very early age and that maternity units may be an important source of early infection. The mild nature of the respiratory illness contrasted with the severity of illness often caused by R.S. virus in older infants. Even in the young infant this virus was associated with clinical symptoms, and it was not found in children without respiratory symptoms. In the course of the investigation the fluorescent antibody technique, applied to aspirates from these very young infants, proved to be a rapid and efficient means of diagnosing R.S. virus infection.

In future winters it is hoped to investigate similar outbreaks, particularly to locate the source of infection and study more closely the nature of the illness caused by R.S. virus in early infancy. In view of previous suggestions on the pathogenesis of bronchiolitis, it would be very important to follow up histories of the subsequent respiratory illnesses in as many as possible of these children who have acquired an R.S. virus infection early in life.

We are indebted to the staff of the Princess Mary Maternity Hospital and of the department of virology for collection and transportation of specimens.

\section{G. A. NELIGAN, D.M., F.R.C.P.}

H. STEINER, M.R.C.P., D.C.H., D.OBST.R.C.O.G.

The Princess Mary Maternity Hospital, Newcastle upon Tyne, and Department of Child Health, University of Newcastle upon Tyne.

\section{P. S. GARDNER, M.D., DIP. BACT.}

J. MCQuIlLIN, B.SC.

Department of Virology, Royal Victoria Infirmary and University of Newcastle upon Tyne.

\section{REFERENCES}

Berkovich, S., and Taranko, L. (1964). Pediatrics, 34, 753. Gardner, P. S., and McQuillin, J. (1968). British Medical fournal, 3, 340

Gardner, P. S., and McQuillin, J. (1970). Unpublished laboratory data Gardner, P. S., McQuillin, J., and Court, S. D. M. (1970). British Medical fournal, 1, 327

Javett, S. N., et al. (1956) fournal of Pediatrics, 48, 1.

Kuroya, M., Ishida, N., and Shiratori, T., (1953). Yokohama Medical Bulletin, 4, 217

McQuillin, J., and Gardner, P. S. (1968). British Medical fournal, 1 602. Sturdy, P. M., McQuillin, J., and Gardner, P. S. (1969). fournal of
Hygiene, 67, 659.
The only previous abdominal crisis I had suffered was an attack of. acute gangrenous appendicitis in 1907; an abscess formed and was drained, and later the stump of the appendix was removed at another operation.

For six months before my recent illness I occasionally had attacks of profuse sweating and increased pulse rate that woke me from sleep, but usually passed off within half an hour. They were not accompanied by any pain. A physician found my heart normal.

On 3 April, 1969 I arose about 7 a.m., enjoyed a simple break- fast, and was up and about all the morning. Then, almost exactly at noon, I suddenly felt a dull severe, deep pain in the middle of the epigastrium. I lost all appetite for food and retired to bed. I wondered what might be the cause of the pain, and thought first of coronary thrombosis, but the pulse was normal in every respect, and there were no symptoms to support this diagnosis. My attention was then directed to the abdomen. I palpated the left side and the right iliac region without finding anything abnormal. In the right hypochondrium, however, a surprise awaited me, for in the normal position of the gall bladder was a rounded, tense, and firm swelling, about the size of a small golf-ball. It was not painful or tender. This absence of tenderness probably put all thoughts of acute cholecystitis out of my mind. I decided to phone an experienced medical practitioner, and he arranged to visit me that afternoon. As I rested in bed the epigastric pain became easier and I dozed a little on and off, and did not even once feel if the abnormal swelling had changed. The physician arrived later in the afternoon, examined the abdomen very carefully, but found no abnormal swelling in the gall-bladder area, nor anywhere else in the abdomen. This greatly surprised me, but I was able to confirm that the swelling I had felt had now completely disappeared. Both pain and swelling having now gone it was agreed that there was no need for any special line of treatment.

I remained comfortable and free from pain for four to five hours. But about 9 p.m. I began to have pain in the right hypochondrium and tenderness in the same area. The pain increased in severity, so I phoned the physician, told him of the change, and asked him to pay me another visit on the morrow. The second visit was paid on 4 April. When the physician saw the position of the pain and tenderness, and found I had a slight rise of tempera- 
ture, he promptly called into consultation a distinguished surgeon, who confirmed the diagnosis of acute cholecystitis and advised my immediate removal to hospital. When I arrived there the diagnosis was again confirmed by a surgeon of vast experience, and he advised immediate operation. This took place that same evening, and a diseased gall bladder, already necrotic in parts, and containing 15 pigment stones, was successfully removed. Convalescence was uneventful, and I was discharged on 18 April.

\section{Comment}

I must now try to relate the symptoms to the course of the disease, and I suggest the following as a possible explanation.

Bacterial action first attacked the mucosa, which responded by a copious secretion of mucus that distended the viscus and caused the epigastric pain. The distension may have been due to the inability of the weak muscle fibres in the wall of the viscus to push the sticky mucus up through the narrow opening of the cystic duct, or maybe a small stone had temporarily stopped up the opening. In either case lying horizontally in bed permitted the mucus to escape from the gall-bladder, relieved the distension, and eased the epigastric pain. During the four to five hours of freedom from pain bacterial action slowly penetrated the whole thickness of the wall of the viscus, and thereupon irritation of the parietal peritoneum led to pain and tenderness in the right hypochondrium. The next stage would have been perforation of the wall of the gall bladder and diffuse peritonitis.

This experience taught me with regard to acute cholecystitis (1) that the first symptom may be epigastric pain, (2) that the first sign may be a distended but not tender gall bladder, (3) that for one reason or another the gall bladder may then be able to expel its contents and both swelling and pain may disappear, (4) that a period of four to five hours may then ensue in which the patient is free of symptoms, and (5) that for the first time pain may now be felt in the right hypochondrium and lead to tenderness on gentle deep palpation, and so to suspicion of the true diagnosis. This sequence is important and is similar to that pointed out many years ago by J. B. Murphy in cases of acute appendicitis.

I do not know whether the nocturnal bouts of sweating and rise in pulse rate had any connexion with the presence of gall stones, but it may be of significance that since the operation a year ago I have not had a similar attack. Finally, I learned the truth of the saying that "one is never too old to learn."

I am deeply grateful for the great skill and constant kindness of all those who so successfully brought me through such a serious illness.

London N.W.1.

ZACHARY COPE, M.D., M.S., F.R.C.S.

\section{Vitiligo and Gastric Carcinoma}

\section{British Medical fournal, 1970, 3, 148}

Patients with vitiligo have an increased incidence of pernicious anaemia, and patients with pernicious anaemia have a high incidence of gastric carcinoma. We here report the case of a man who presented with anaemia and vitiligo and was found to have a gastric carcinoma.

\section{CASE Report}

The patient, a 46-year-old brickyard worker, was first admitted to hospital in November 1961 with a one-year history of sleeplessness, a swelling in the neck, and increasingly prominent eyes. An enlarged nodular thyroid gland and exophthalmos were present on examination. Thyrotoxicosis was diagnosed being confirmed by an increased ${ }^{131} \mathrm{I}$ uptake. The haemoglobin was $72 \%$, P.C.V. $35 \%$, and M.C.H.C. $31 \%$. The blood film showed hypochromia and anisocytosis. A subtotal thyroidectomy was performed, which relieved his symptoms.

He was readmitted to hospital in September 1969 with a 14month history of epigastric pain (relieved by alkalis), lassitude and weight loss for two months, and vomiting for one month. He was pale with a slight lemon tinge, grey-haired, and had pronounced vitiligo on both hands and forearms. There was no abdominal mass, but a gastric succussion splash was heard.

Investigations.-Haemoglobin $38 \%$; P.C.V. $23 \%$; M.C.H.C. $24 \%$; reticulocytes $2.8 \%$. Film showed gross hypochromia, anisocytosis, and poikilocytosis. W.B.C. and platelet counts were normal. Bone marrow showed increased cellularity, suggesting iron deficiency or haemorrhage. Serum iron was $14 \mu \mathrm{g} . / 100 \mathrm{ml}$., and iron-binding capacity $318 \mu \mathrm{g} . / 100 \mathrm{ml}$. Serum vitamin $\mathrm{B}_{12}$ level was less than $100 \mathrm{pg} . / \mathrm{ml}$. Occult blood was detected in the faeces after five seconds. Urea and electrolytes were within normal limits. Plasma protein level was $7.0 \mathrm{~g} . / 100 \mathrm{ml}$., with excess $\gamma$ globulins. Fasting blood sugar $100 \mathrm{mg} . / 100 \mathrm{ml}$; P P.B.I. $4 \mu \mathrm{g} . / 100$ ml.; cholesterol $160 \mathrm{mg} . / 100 \mathrm{ml}$. Barium meal examination showed a stenosing carcinoma of the antrum. Malignant cells were not found in gastric washings. Gastric acid secretion (in response to intramuscular pentagastrin $6 \mu \mathrm{g}$. $/ \mathrm{kg}$.) was $9.8 \mathrm{mEq} /$ hour. Gastric parietal cell antibodies were present in excess. Intrinsic factor antibodies were absent and thyroid antibodies and antinuclear factor were not detected.

He was given 8 units of blood before operation, when an infiltrating carcinoma of the stomach involving adjacent lymph nodes was found. A Polya gastrectomy was perfomed (C.W.V.) The lesion was a moderately well differentiated adenocarcinoma penetrating the wall of the stomach and invading local lymph nodes. The remainder of the gastric mucosa showed chronic inflammatory changes but no atrophy. He made a good recovery and was discharged home symptom-free.

\section{COMMENT}

Various neoplasms of the intestine are associated with signs in the skin. Vitiligo and carcinoma of the stomach may have occurred in this patient by chance. It is, however, reasonable to expect an increased incidence of carcinoma of the stomach in patients with vitiligo, since a high incidence of pernicious anaemia has been found in patients with this skin condition (Allison and Curtis, 1955) and low gastric acid secretion has been reported (Francis, 1931; Allison, 1945). The evidence for pernicious anaemia in this patient is based on the low serum vitamin $B_{12}$ estimation, the blood picture being obscured by the gross hypochromic anaemia due to the bleeding carcinoma of the stomach. Both low gastric acidity and raised titre of gastric parietal cell antibody were present.

This case is also of interest as it confirms the association of vitiligo with autoimmune diseases; for not only did the patient show signs of gastric autoimmune disease but on his original admission he had Graves's disease-a thyroid autoimmune disorder.

ADDENDUM.-The patient was seen again as an out-patient nine months postoperatively. His vitiligo had become much less obvious and there was no evidence of recurrence of his gastric carcinoma.

Our thanks are due to Professor I. D. A. Johnston, under whose care this patient was admitted, and Professor S. Shuster for their helpful advice.

\section{P. D. WRIGHT, M.B., B.S., \\ Senior House-officer, Department of Surgery. \\ C. W. VENABLES, M.B., B.S., F.R.C.S., First Assistant, Department of Surgery. \\ R. P. R. DAWBER, M.B., B.S., M.R.C.P., Registrar, Department of Dermatology.}

Royal Victoria Infirmary, Newcastle upon Tyne NE1 4LP. REFERENCES

Allison, J. R. (1945). Southern Medical fournal, 38, 235

Allison, J. R., and Curtis, A. C. (1955). Archives of Dermatology, 72, Francis, H. W. (1931). Nebraska State Medical fournal, 16, 25. 